\title{
Hubungan antara tekanan darah dan gula darah dengan kemampuan kognitif siswa pada pembelajaran fisika melalui model pembelajaran search, solve, create, and share (sscs) di SMA 4 Bengkulu Utara
}

\author{
Susmiyarti $^{1,2}$, Muhammad Farid ${ }^{3}$, Afrizal Mayub ${ }^{1}$ \\ ${ }^{1}$ Pascasarjana Pendidikan IPA FKIP Universitas Bengkulu \\ ${ }^{2}$ SMAN 4 Bengkulu Utara \\ ${ }^{3}$ Jurusan Fisika FMIPA Universitas Bengkulu \\ *E-mail : susmiyarticuaspd@gmail.com
}

DOI: https://doi.org/10.33369/pendipa.3.3.132-141

\begin{abstract}
[The Relationship Between Blood Pressure and Blood Sugar with the Cognitive Ability of Students in Physics Learning Through the Search, Solve, Create and Share (SSCS) Learning Model at SMA 4 Bengkulu Utara]. The purpose of this study is to describe the correlation of blood pressure and blood sugar with student achievement in physics learning through the SSCS learning model at SMAN 4 North Bengkulu. The research method is descriptive-analytic with a cross-sectional study approach. From the results of the blood pressure correlation test and student achievement through the SSCS learning model, it was found that $p=0.828>0.05$, which means that the null hypothesis was accepted, that blood pressure did not have a significant relationship with learning achievement. Furthermore, the value of $r=0.022$ which has a relationship with the category is very weak. rom the results of the correlation test of blood sugar and student achievement through the SSCS learning model, it was found that $p=0.932>0.05$ which means that the null hypothesis is accepted, that blood sugar does not have a significant relationship with learning achievement. Furthermore, the $r$ value $=0.134$ which has a relationship with a very weak category. So from the results of the analysis above, it can be concluded that there is no relationship between blood pressure and blood sugar with physics learning achievement of students of class X MIPA and XI MIPA at SMAN 4 North Bengkulu.
\end{abstract}

Keywords: Blood Pressure; Blood Sugar; Learning Achievement; Physics Learning; SSCS Model.

(Received July 9, 2019; Accepted August 5, 2019; Published October 16, 2019)

\begin{abstract}
ABSTRAK
Tujuan penelitian ini yaitu mendeskripsikan hubungan antara tekanan darah dan gula darah dengan kemampuan kognitif siswa pada pembelajaran fisika melalui model pembelajaran SSCS di SMAN 4 Bengkulu Utara. Metode penelitian ini yaitu deskriptif-analitik dengan melalui metode korelasi. Dari hasil uji korelasi tekanan darah dan prestasi belajar siswa melalui model pembelajaran SSCS yang diajarkan secara tidak langsung kepada siswa selama pengambilan data tekanan darah dan gula darah siswa didapat bahwa $\mathrm{p}=0,828>0,05$ yang artinya hipotesis nol diterima yaitu tekanan darah tidak memiliki hubungan yang signifikan dengan kemampuan kognitif. Selanjutnya, nilai $r=0,022$ yang memiliki hubungan dengan kategori sangat lemah antara tekanan darah dan kemampuan kognitif siswa. Dari hasil uji korelasi gula darah dan kemampuan kognitif siswa melalui model pembelajaran SSCS didapat bahwa $\mathrm{p}=0,932>0,05$ yang artinya hipotesis nol diterima yaitu gula darah tidak https://ejournal.unib.ac.id/index.php/pendipa
\end{abstract}


memiliki hubungan yang signifikan dengan kemampuan kognitif. Selanjutnya, nilai $r=0,134$ yang memiliki hubungan dengan kategori sangat lemah. Sehingga dari hasil analisis di atas, dapat disimpulkan bahwa tidak ada hubungan antara tekanan darah dan gula darah dengan kemampuan kognitif fisika siswa kelas X MIPA dan XI MIPA di SMAN 4 Bengkulu Utara.

Kata kunci: Tekanan Darah; Gula Darah; Kemampuan kognitif; Pembelajaran Fisika; Model SSCS

\section{PENDAHULUAN}

Masa remaja merupakan masa transisi (peralihan) dari masa anak ke masa dewasa yang berlangsung lama dan berbeda waktu kematangannya antara pria dan wanita. Usia kematangan pada pria terjadi pada umur 20 sampai 22 tahun, sedangkan pada wanita 1 sampai 2 tahun lebih dahulu sehingga menimbulkan masalah dalam hubungan sosial (Hassan and Alatas, 1998). Remaja sering dianggap sebagai periode yang paling sehat dalam siklus kehidupan, akan tetapi untuk tercapainya tumbuh kembang remaja yang optimal tergantung pada potensial biologinya. Tingkat tercapainya potensi biologi seseorang remaja merupakan hasil interaksi faktor genetik dan lingkungan biopsikososial (Dhamayanti, 2015).

$$
\text { Sarafino (1990) dalam }
$$

tinjauannya memandang remaja sebagai kelompok yang mempunyai banyak risiko yang berkaitan dengan kualitas kesehatannya. Kondisi tersebut disebabkan adanya karakteristik yang spesifik dalam proses perkembanganya yaitu dengan tingkat kemampuan kognitif dan penalarannya telah mampu memahami dan memutuskan sesuatu secara logis. Dalam hal ini berarti bahwa kesehatan sangat mempengaruhi kemampuan berfikir para remaja.

Dalam kehidupan yang lebih komplek, kesehatan seseorang juga dapat dilihat dari besarnya gula darah. Diabetes Melitus Tipe 2 berhubungan dengan percepatan penurunan fungsi kognitif, dan peningkatan risiko gangguan kognitif ringan hingga demensia (Velayudhan, 2010). Diabetes melitus meningkatkan risiko gangguan penyakit alzheimer dan demensia vaskuler. Resiko akan semakin meningkat ketika diabetes terjadi pada usia pertengahan atau produktif (Xu, 2009).

Berdasarkan hasil observasi data awal mengenai tekanan darah siswa di SMAN 4 Bengkulu Utara khususnya kelas $\mathrm{X}$ MIPA, terdapat 122 siswa dari 242 siswa yang memiliki tekanan darah normal (normotensi), selanjutnya terdapat 5 siswa yang bertekanan darah tinggi (hipertensi) dan 30 siswa yang bertekanan darah rendah (hipotensi). Dari data tersebut dapat disimpulkan bahwa mayoritas siswa kelas X MIPA memiliki tekanan darah normal. Tekanan darah yang tidak normal dapat menimbulkan masalah psikologis, seperti; penurunan konsentrasi belajar, stress, gangguan memori dan menurunnya prestasi akademik (Amalia, 2014). Tekanan darah yang tidak normal juga dapat mengganggu kesehatan siswa, seperti: vertigo, pusing, mual, dan penyakit lainnya (Pitaloka dkk, 2015).

Menurut Lestari (2017) terdapat hubungan signifikan antara tekanan darah dengan gangguan kognitif pada lansia. Demikian juga dikemukakan oleh Wahyuniarti (2013) terdapat hubungan yang signifikan antara hipertensi dengan fungsi kognitif pada lansia di Kelurahan Sumbersari Malang. Pandean (2016) meneliti hubungan antara penderita hipertensi dengan fungsi kognitif di Poliklinik SMF Ilmu Penyakit Dalam RSUP Prof. Dr. R. D. Kandou Manado. Hasil penelitian menunjukkan adanya hubungan yang signifikan antara penderita hipertensi dengan fungsi kognitif pasien yang berobat jalan. 
Baik Lestari (2017), Wahyuniarti (2013), dan Pandean (2016) telah mengetahui hubungan antara penderita hipertensi dengan fungsi kogntitif pada manusia usia lansia dan umur yang bervariasi. Penelitian ketiganya memberikan inspirasi penulis untuk mengetahui hubungan yang khas, yaitu hubungan antara penderita hipertensi atau hipotensi pada usia remaja atau usia anak level SMA (Sekolah Menengah Atas).

Selain itu, menurut pepatah "Mens sana in corpore sano" yang artinya di dalam tubuh yang kuat terdapat jiwa yang sehat pula. Oleh karena itu, peneliti berpendapat bahwa kemampuan kognitif seseorang akan sangat dipengaruhi oleh tingkat kesehatan orang tersebut dan berdasarkan pengalaman yang ada, siswa yang memilki tekanan darah rendah atau kurang sehat biasanya akan memiliki kemampuan kognitif yang lebih rendah dari siswa yang sehat atau bertekanan darah normal. Pernyataan ini timbul di lapangan atau di kehidupan sehari-hari. Hal ini akan menjadi tantangan untuk mengetahui kondisi kemampuan kognitif siswa yang dikaitkan dengan tingkat kesehatan. Untuk meneliti ini sangat menarik jika yang dipilih sebagai sampel adalah siswa yang masih dalam taraf remaja yaitu peralihan dari anak-anak ke dewasa.

Pada proses pembelajaran fisika saat ini, guru dituntut untuk menerapkan model pembelajaran yang mengasah kemampuan berfikir kritis siswa. Model pembelajaran Search, Solve, Create, and Share (SSCS) diperlukan guna menciptakan susasana pembelajaran yang efektif. Pembelajaran efektif adalah pembelajaran yang dapat memacu semangat setiap siswa untuk terlibat secara aktif dalam pengalaman belajarnya baik mental maupun fisik agar tercapainya tujuan dari pembelajaran dan siswa terdorong untuk mengembangkan kemampuan intelektualnya, kemampuan menganalisis, kemampuan menyampaikan pendapat dan pengetahuan, serta mengembangkan kemampuan berpikir kritis.

Model pembelajaran Search, Solve, Create, and Share(SSCS) adalah model pembelajaran yang terpusat pada aktivitas siswa (student centered) dan menggunakan pendekatan problem solving. Fokus dari penerapan model pembelajaran SSCS ini adalah membantu siswa untuk melakukan pemecahan masalah secara nyata dan mandiri,membangkitkan minat bertanya asiswa, dan melibatkan siswa secara aktif dalam menyelidiki sesuatu, sehingga mampu meningkatkan kemampuan berpikir kritis siswa. Sebagaimana Pizzini (1996, 3) menyatakan bahwa "The SSCS Problem Solving Model is designed to expand and apply science concepts and critical thinking skills". Menurut Pizzini, model pembelajaran SSCS memang didesain untuk mengembangkan pemahaman konsep dan mengembangkan kemampuan berpikir kritis siswa. tujuan penelitian ini yaitu; (1) Untuk mendiskripsikan hubungan antara tekanan darah dengan kemampuan kognitif siswa pada pembelajaran fisika melalui model pembelajaran SSCS di SMAN 4 Bengkulu Utara; dan (2) Untuk mendiskripsikan hubungan antara gula darah dengan kemampuan kognitif siswa pada pembelajaran fisika melalui model pembelajaran SSCS di SMAN 4 Bengkulu Utara. 


\section{METODE PENELITIAN}

Penelitian ini menggunakan metode penelitian deskriptif-analitik dengan pendekatan cross sectional study (studi potong lintang) yang bertujuan untuk mengetahui hubungan tekanan darah dengan kesehatan melalui model pembelajaran Search, Solve, Create, and Share(SSCS) pada pembelajaran fisika di SMAN 4 Bengkulu Utara. Pengumpulan data untuk jenis penelitian ini dilakukan secara bersama-sama atau sekaligus dalam satu waktu. Populasi penelitian ini adalah seluruh siswa kelas X MIPA dan XI MIPA SMAN 4 Bengkulu Utara (angkatan 2018) yang terdiri dari 100 siswa. Pengambilan sampel dilakukan dengan cara total sampling, dimana semua populasi menjadi sampelnya yaitu seluruh siswa kelas $\mathrm{X}$ dan XI MIPA SMAN 4 Bengkulu Utara.

Dalam penelitian ini, terdapat tiga instrumen yang digunakan sebagai kebutuhan riset, yaitu: tes (ujian tengah semester), pengukuran tekanan darah, dan pengukuran gula darah. Peneliti akan meminta bantuan pihak UKS sekolah untuk mengukur tekanan darah dan gula darah siswa. Tekanan darah normal yaitu tidak lebih dari 120/80 dan tidak mencapai 90/60. Jika siswa memiliki tekanan darah lebih dari 120/80 dapat disimpulkan bahwa siswa memilki tekanan darah tinggi dan sebaliknya jika mencapai 90/60 maka disimpulkan bahwa siswa memiliki tekanan darah rendah. Selanjutnya, siswa dinyatakan memiliki gula darah normal jika tidak lebih dari 140 dan tidak mencapai $<60$.

Penelitian ini menggunakan metode penelitian deskriptif-analitik dengan pendekatan cross sectional study (studi potong lintang) yang bertujuan untuk mengetahui hubungan tekanan darah dan gula darah dengan kemampuan kognitif siswa pada pelajaran fisika melalui model pembelajaran SSCS di SMAN 4 Bengkulu Utara khususnya kelas $X$ dan XI MIPA. Adapun langkahlangkahnya yaitu sebelum melakukan penelitian, peneliti akan mengukur tekanan darah dan gula darah terhadap siswa yang menjadi subjek penelitian. Selanjutnya untuk mengetahui kemampuan kognitif siswa melalui model pembelajaran SSCS peneliti memberikan beberapa soal mid test. Analisis yang digunakan dalam penelitian ini yaitu analisis bivariat. Analisis bivariat dalam penelitian ini adalah untuk mengetahui hubungan tekanan darah dan gula darah dengan kemampuan kognitif siswa pada pembelajaran fisika yang diolah secara statistik menggunakan program komputer SPSS versi 16.0 for Windows dengan uji korelasi Spearman Rank (Rho) karena variabel penelitian berskala ordinal. Untuk mengetahui adanya hubungan yang signifikan antara variabel bebas dengan variabel terikat dengan taraf kesalahan 5\% ( $\mathrm{p}$ value 0,05 ) apabila didapatkan nilai $\mathrm{p}$ value $\leq 0,05$ yang berarti bahwa $\mathrm{Ha}$ diterima dan Ho ditolak (Hidayat, 2007). 


\section{HASIL DAN PEMBAHASAN}

Hubungan antara tekanan darah dan kemampuan kognitif fisika siswa kelas $X$ MIPA dan XI MIPA di SMAN 4 Bengkulu Utara

Setelah memperoleh dan menganalisis data tekanan darah dan kemampuan kognitif siswa, peneliti

Tabel 1. Hubungan Tekanan Darah dan Kemampuan kognitif

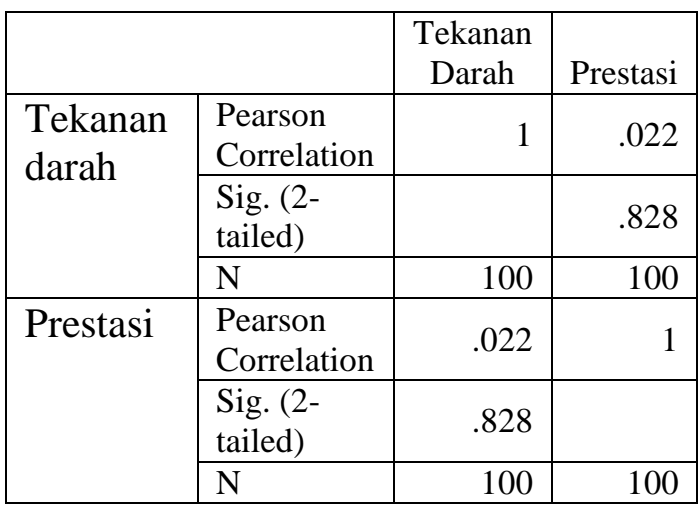

Dari hasil uji korelasi tekanan darah dan kemampuan kognitif siswa melalui model pembelajaran SSCS didapat bahwa $\mathrm{p}=0,828>0,05$ yang artinya hipotesis 0 diterima yaitu tekanan darah tidak memiliki hubungan yang signifikan dengan kemampuan kognitif. Selanjutnya, nilai $\mathrm{r}=0,022$ yang memiliki hubungan dengan kategori sangat lemah. Sehingga dari hasil analisis di atas, dapat disimpulkan bahwa tidak ada hubungan antara tekanan darah dan kemampuan kognitif fisika siswa kelas X MIPA dan XI MIPA di SMAN 4 Bengkulu Utara.

Tidak ada hubungan antara tekanan darah dan kemampuan kognitif siswa pada penelitian ini dikarenakan bahwa rata-rata keseluruhan siswa yang dijadikan sampel penelitian ini berusia produktif sehingga memiliki tekanan darah normal. Hasil menganalisis hubungan tekanan darah terhadap kemampuan kognitif siswa menggunakan analisis bivariat. Analisis bivariate menggunakan analisis product moment dari Pearson melalui aplikasi SPSS 16 untuk menguji hubungan tekanan darah siswa terhadap kemampuan kognitif, hasil analisis didapat sebagai berikut:

penelitian menunjukkan bahwa hanya terdapat sebagian kecil siswa yang memilki tekanan darah tinggi dan rendah. Siswa yang memiliki tekanan darah yang rendah, tinggi, ataupun normal tidak mempengaruhi kemampuan kognitif mereka.

Menurut Finegold dkk (2013), kondisi tekanan darah kemungkinan berkaitan dengan penurunan fungsi kognitif. Hipertensi dapat meningkatkan terjadinya gangguan vaskularisasi pada otak, yang tentunya akan berpengaruh terhadap sistem kinerja otak yang menjadi pusat kognitif. Pembuluh darah yang memasok oksigen dan nutrisi pada area grey matter dan white matter tersebut juga memiliki peranan penting terhadap sistem kognitif. Tekanan darah yang normal, memberikan vaskularisasi yang cukup pada area otak tersebut. Namun, ketika tekanan darah mengalami kenaikan (Hipertensi), ataupun mengalami penurunan (Hipotensi), menyebabkan vaskularisasi pada area otak grey matter dan white matter juga terganggu. Kekurangan oksigen ataupun nutrisi karena hipertensi ataupun hipotensi, menyebabkan terjadinya hypoxia pada area grey matter dan white matter di otak, kemudian manifestasi selanjutnya adalah menurunnya fungsi kognitif. 
Hipertensi berhubungan dengan fungsi kognitif, terutama pada Executive Functioning (EF). Executive Functioning merupakan suatu sistem kemampuan mental pada otak yang terkontrol oleh area lobus frontal, yang berasosiasi dengan kemampuan menejemen dan atensi seseorang. Fenomena ini berhubungan dengan terjadinya penurunan $\mathrm{CBF}$ (Cerebral Blood Flow) pada area lobus frontal pada kasus hipertensi, yang mana

Executive dysfunction yang terjadi pada area frontal (prefrontal, dorsolateral, orbitofrontal, dan anterior cingulate) ditandai dengan adanya kelemahan pada performa mental, perubahan visual dan spasial, sulit merencanakan sesuatu dan memulai aktivitas, yang kemudian akan berdampak pada memori jangka pendek, dan emosi yang tidak stabil (Vicario, dkk. 2005).

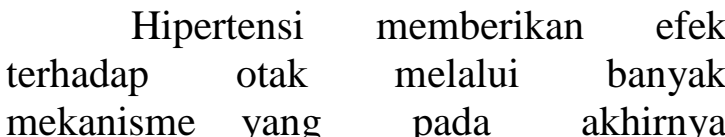
memberikan efek terhadap penurunan fungsi kognitif (Vicario, dkk. 2005). Beberapa studi telah dilakukan dan didapatkan hasil bahwa hipertensi menyebabkan penurunan cerebral blood flow (CBF) dan metabolisme otak(penggunaan glukosa untuk menghasilkan energi) pada regio otak tertentu, seperti pada lobus frontal, temporal, dan area subkortikal. Penurunan CBF ini ditemukan lebih besar efek yang ditimbulkan pada pasien hipertensi tanpa terapi medikasi dibandingkan dengan pasien yang mendapatkan terapi obat. Beberapa penelitian selanjutnya juga menunjukkanbahwa pada subjek penderita hipertensi memiliki respon yang lebih buruk pada fungsi memorinya dibandingkan dengan yang memiliki tekanan darah normal (Vicario, dkk. 2005). akan berdampak pada Executive Functioning System (Elias, dkk. 2012). Beberapa skil yang dimiliki EF termasuk inhibitory control, working memory, dan cognitive flexibility, merupakan komponen yang terlibat dalam perencanaan sesuatu, pengingatan informasi, dan pertimbangan keputusan dalam mencapai suatu tujuan atau pemecahan masalah (problem solving) (Zelazo, dkk. 2017).

Penemuan ini menunjukkan bahwa CBF memiliki peranan penting pada fungsi memori dan juga pada fungsi kognitif yang lain. Transmisi neurokimiawi pada otak dan pada fungsi basal sel juga terkena efek akibat dari hipertensi, selain itu berbagai macam karakteristik neurofisiologis hipertensi juga dapat memberikan andil terhadap gangguan fungsi kognitif. Beberapa karakteristik ini juga dapat menyebabkan perubahan patologis pada anatomi otak setelah melalui beberapa tahun.Pembuluh darah besar yang memberikan suplainya ke otak (arteri carotis) serta pembuluh darah besar dan pembuluh darah kecil yang berada didalam otak juga terkena imbas dari hipertensi.

Hipertensi menyebabkan kerusakan pada endotel dari arteri serebral. Kerusakan ini dapat menimbulkan gangguan padablood brain barrier,sehingga substansi toksik dapat dengan mudah masuk menuju ke otak. Selain itu kerusakan pembuluh darah menurunkan suplai darah ke otak, atherosclerosispada arteri besar dan blokade pada arteriol. Pada akhirnya proses ini menyebabkan kerusakan pada substansia alba yang berperan dalam transmisi pesan dari satu regio otak menuju yang lainnya, selain itu juga menyebabkan mini stroke atau sering disebutsilent infarctionkarena simptom yang muncul tidak terlihat dengan jelas. 
Pada penderita hipertensi yang mengkonsumsi obat ditemukan kerusakan pada substansia alba tidak sehebat pada penderita tanpa mengkonsumsi obat anti hipertensi, dan juga pada penderita yang tekanan darahnya tidak terkontrol terlihat kerusakan yang ekstensif. Pada tahap akhir penderita hipertensi ditemukan bahwa terjadi atropi atau penyusutan pada massa otaknya. Berbagai gangguan inilah yang secara bertahap menimbulkan vascular disease pada otak yang pada tahap akhir menimbulkan stroke ataupun demensia vaskuler.

Menurut penelitian Mcload dan Teesta (2017), penurunan kognitif berhubungan dengan kejadian cerebral hypoperfusion. Dalam penelitiannya, responden yang telah diberikan passive exercise, terjadi peningkatan tekanan darah diastolik sebesar $6.1 \mathrm{mmHg}$ dan memiliki performa kognitif yang lebih baik, dibandingkan dengan responden dengan hypotension (tekanan darah diastolic $<70$ $\mathrm{mm} \mathrm{Hg}$ ). Penelitian dari 74 responden yang berusia 30-75 tahun, responden dengan hypotension, relative memiliki penurunan pada memori verbal, dan konsentrasi. Hal tersebut kemungkinan disebabkan oleh adanya lesi white matter atau juga disebut leukoaraiosis yang mungkin berkembang seiring waktu, sebagai akibat dari hipoperfusi serebral (Czajkowska, dkk. 2010).

Dari hasil penelitian di atas, tidak menunjukkan adanya pengaruh penurunan kognitif yang diakibatkan oleh tekanan darah tinggi atau rendah pada usia anakanak atau remaja. Penurunan kognitif biasanya terjadi pada usia dewasa yang berusia di atas 30 tahun. Pasien usia lanjut yang menderita hipertensi lebih dari lima tahun dapatkan menderita penurunan fungsi kognitif (Taufik, 2014). Keadaan penurunan fungsi kognitif pada usia lanjut, lebih sering didapat pada hipertensi kronik. Keadaan ini terjadi karena penyempitan dan sklerosis arteri kecil di daerah
Tekanan darah rendah berasosiasi dengan penurunan fungsi neuro psikologi pada orang dewasa normal. Hipotensi juga kemungkinan berkontribusi pada penuruna kognitif melalui penurunan perfusi serebral (Cerebral Perfusion), yang kemungkinan berefek pada beberapa area otak. Hipotensi dapat menurunkan $\mathrm{CBF}$ dan meningkatkan terjadinya lesi akibat ischemic atau anoxia pada otak, terutama pada area hippocampus. Hal tersebut menyebabkan terjadinya penurunan kemampuan memori pada tes neuro psikologi (Davis, dkk. 2003).

subkortikal, yang mengakibatkan hipoperfusi, kehilangan autoregulasi, penurunan sawar otak, dan pada akhirnya terjadi proses demyelinisasi white matter subcortical, mikroinfark dan penurunan kognitif. Pemeriksaan MRI pada pasien dengan hipertensi kronik sering mendapatkan lesi subkortikal, mikroinfark, astrogliosis, pelebaran ventrikel, dan akumulasi cairan ekstrasel dibanding yang tanpa hipertensi (Suhardjono, 2009).

Hasil penelitian ini didukung oleh Lestari dkk (2017) yang mendapatkan hasil penelitian berdasarkan uji statistik yang telah dilakukan untuk mengetahui hubungan gangguan fungsi kognitif dengan hipertensi pada lansia di Panti Tresna Werdha Khusnul Khotimah Pekanbaru, ditemukan hubungan yang tidak bermakna antara gangguan fungsi kognitif dengan hipertensi menggunakan uji fisher didapatkan nilai $\mathrm{p}$ sebesar 1,000 ( $>0,05)$. Berdasarkan tingkat pendidikan, hasil penelitian menunjukkan sebanyak 17 subjek dari 23 subjek dengan pendidikan rendah mengalami hipertensi. Subjek dengan tingkat pendidikan tinggi dari 8 subjek terdapat 6 subjek (75\%) diantaranya mengalami hipertensi. Berdasarkan hasil penelitian ini menunjukkan bahwa semakin rendah pendidikan seseorang maka semakin tinggi pula kejadian hipertensi. 
Penelitian oleh Taufik (2014) juga mendukung hasil penelitian ini. Berdasarkan hasil penelitian, dapat disimpulkan bahwa Terdapat gangguan fungsi kognitif pada subjek penelitian yang memiliki riwayat hipertensi lebih dari 5 tahun, terutama pada komponen atensi. Namun tidak terdapat hubungan yang bermakna pada subjek yang saat ini menderita hipertensi dengan gangguan fungsi kognitif. Terdapat beberapa variabel seperti pendidikan, lamanya riwayat hipertensi, merokok, yang memiliki pengaruh bermakna pada subjek penelitian

Tabel 2. Hubungan Gula Darah dan Kemampuan kognitif

\begin{tabular}{|l|l|r|r|}
\hline \multicolumn{2}{|c|}{} & \multicolumn{1}{|c|}{$\begin{array}{c}\text { Gula } \\
\text { Darah }\end{array}$} & Prestasi \\
\hline $\begin{array}{l}\text { Gula } \\
\text { Darah }\end{array}$ & $\begin{array}{l}\text { Pearson } \\
\text { Correlation }\end{array}$ & 1 & .134 \\
\cline { 2 - 4 } & $\begin{array}{l}\text { Sig. (2- } \\
\text { tailed) }\end{array}$ & & .932 \\
\cline { 2 - 4 } & N & 100 & 100 \\
\hline Prestasi & $\begin{array}{l}\text { Pearson } \\
\text { Correlation }\end{array}$ & .134 & 1 \\
\cline { 2 - 4 } & $\begin{array}{l}\text { Sig. (2- } \\
\text { tailed) }\end{array}$ & .932 & \\
\cline { 2 - 4 } & N & 100 & 100 \\
\hline
\end{tabular}

Dari hasil uji korelasi gula darah dan kemampuan kognitif siswa melalui model pembelajaran SSCS didapat bahwa $\mathrm{p}=0,932>0,05$ yang artinya hipotesis 0 diterima yaitu gula darah tidak memiliki hubungan yang signifikan dengan kemampuan kognitif. Selanjutnya, nilai $\mathrm{r}=0,134$ yang memiliki hubungan dengan kategori sangat lemah. Sehingga dari hasil analisis di atas, dapat disimpulkan bahwa tidak ada hubungan antara gula darah dan kemampuan kognitif fisika siswa kelas $\mathrm{X}$ MIPA dan XI MIPA di SMAN 4 Bengkulu Utara.

Tidak ada hubungan antara gula darah dan kemampuan kognitif siswa pada penelitian ini dikarenakan bahwa rata-rata keseluruhan siswa yang dijadikan sampel penelitian ini berusia produktif sehingga memiliki gula darah normal. Hasil dengan riwayat hipertensi terhadap gangguan fungsi kognitif.

Hubungan antara gula darah dan kemampuan kognitif fisika siswa kelas $X$ MIPA dan XI MIPA di SMAN 4 Bengkulu Utara

Pada analisis hubungan gula darah dan kemampuan kognitif ini, peneliti juga menggunakan kategorisasi yang sama dengan analisis hubungan tekanan darah dan kemampuan kognitif sebelumnya. Berdasarkan hasil analisis korelasi yang telah dilakukan didapatkan hasil sebagai berikut:

penelitian menunjukkan bahwa hanya terdapat sebagian kecil siswa yang memilki gula darah tinggi. Siswa yang memiliki gula darah yang tinggi ataupun normal tidak mempengaruhi kemampuan kognitif mereka.

Dikarenakan usia sampel yang produktif, hasil analisis data yang sudah dilakukan sesuai dengan landasan teori yang sudah dijabarkan sebelumnya bahwa kadar glukosa atau gula darah yang tinggi dapat mengakibatkan terbentuknya radikal bebas sehingga memicu terjadinya stres oksidatif. Stres oksidatif dapat meyebabkan kerusakan pada berbagai sel di dalam tubuh tidak terkecuali sel yang berada di otak sehingga fungsi kognitif dapat terganggu (Vijayakumar, 2014). Penelitian yang dilakukan oleh Luchsinger selama 4,3 tahun juga menunjukkan bahwa terdapat hubungan antara diabetes dengan cognitive impairment dan alzheimer disease.

Mekanisme yang mendasari hubungan yang memungkinkan antara diabetes dengan gangguan fungsi kognitif masih belum sepenuhnya jelas (Luchsinger et. al, 2001). Selain itu, penelitian yang dilakukan Moore et. al menunjukkan bahwa individu dengan diabetes melitus mempunyai fungsi kognitif yang lebih buruk daripada individu tanpa Diabetes Melitus (Moore et. al, 2013). 
Kadar glukosa darah sepanjang hari bervariasi dimana akan meningkat setelah makan dan kembali normal dalam waktu 2 jam. Kadar glukosa darah yang normal pada pagi hari setelah malam sebelumnya berpuasa adalah 70-110 $\mathrm{mg} / \mathrm{dL}$ darah. Kadar glukosa darah biasanya kurang dari 120-140 mg/dL pada 2 jam setelah makan atau minum cairan yang mengandung glukosa maupun karbohidrat lainnya (Price, 2005). Kadar

\section{KESIMPULAN}

Dari hasil penelitian yang ditemukan, maka kesimpulan dalam penelitian ini yaitu: (1) Ada hubungan antara tekanan darah dan kemampuan kognitif fisika melalui model pembelajaran SSCS pada siswa kelas X MIPA dan XI

\section{REFERENCES}

Abadi K, Wijayanti D, Gunawan EA, Rumawas ME, Sutrisna B. (2013). Hipertensi dan risiko mild cognitive impairment pada pasien usia lanjut. Jurnal Kesehatan Masyarakat Nasional; 8(3): 11924.

Baghianimoghadam, M.H., Rahaee, Z., Morowatisharifabad, M.A., Sharifirad, G., Andishmand, A., \& Azadbakht, L. (2009). Effect of education on selfmonitoring of blood pressure Based on BASNEF model in hypertensive patients. Journal of Research in Medical Sciences, 15(2), 70-77.

Bayo, M.B., (2008). Pengaruh pendidikan kesehatan terhadap pengetahuan klien tentang cara pencegahan hipertensi di kelurahan tijomoyo semarang.

Beigi, M.A., Zibaeenezad M.J., Aghasadeghi K., Aghasadeghi, K., Jokar, A., Shekarforoush, S., \& Khazraei, H. (2014). The effect of educational program on glukosa darah yang normal cenderung meningkat secara ringan tetapi bertahap setelah usia 50 tahun, terutama pada orang- orang yang tidak aktif bergerak. Peningkatan kadar glukosa darah setelah makan atau minum merangsang pankreas untuk menghasilkan insulin sehingga mencegah kenaikan kadar glukosa darah yang lebih lanjut dan menyebabkan kadar glukosa darah menurun secara perlahan.

MIPA di SMAN 4 Bengkulu Utara namun lemah dan tidak signifikan dan; (2) Ada hubungan antara gula darah dan kemampuan kognitif fisika melalui model pembelajaran SSCS pada siswa kelas $\mathrm{X}$ MIPA dan XI MIPA di SMAN 4 Bengkulu Utara namun lemah dan tidak signifikan..

hypertension management. International Cardiovascular Research Journal, 8(3) 94-98.

Branch, W.T., Alexander R.W., Schlanta R.C., \& Hurst J.W. (2000). Cardiology in primary care. New York: McGraw-Hill Companies.

Czajkowska, J., Ozhog, S., Smith, E., \& Perlmuter, L. C. (2010). Cognition and Hopelessness in Association With Subsyndromal Orthostatic Hypotension, 65(May), 873-879. https://doi.org/10.1093/gerona/glq0 $\underline{68}$

Dastoorpour, M., et al. (2014). The effect of health promoting intervention on healthy lifestyle and social support in elders: a clinical trial study. Iranian Red Crescent Medical Journal, 16 (8).

Davis, R. N., Massman, P. J., \& Doody, R. S. (2003). Effects of blood pressure on neuropsychological functioning in Alzheimer' $\mathrm{s}$ disease, 18, 1932. 
Elias, M. F., Goodell, A. L., \& Dore, G. A. (2012). Hypertension and Cognitive Functioning A Perspective in Historical Context. American Heart Association. https://doi.org/10.1161/HYPERTE NSIONAHA.111.186429

Friedman, M.M. (2010). Buku ajar keperawatan keluarga: riset, teori, \& praktik/ Marilyn M. Friedman, Vicky R, Bowden, Elaine G. Jones; Jakarta: EGC

Finegold, J. A., Asaria, P., \& Francis, D. P. (2013). Mortality from ischaemic heart disease by country, region, and age: Statistics from World Health Organisation and United Nations. International Journal of Cardiology, 168(2), 934-945.

https://doi.org/10.1016/j.ijcard.201 2.10 .046

Jafar, T.H., Islam, M., Hatcher, J., Hashmi, S., Bux, R., Khan, A., et al, (2010). Community based lifestyle intervention for blood pressure reduction in children and young adults in developing country, BioMedical Journal, 340.

Kumar, V., Abbas, A.K., Fausto, N., (2005). Hypertensive Vascular Disease. Dalam: Robin and Cotran Pathologic Basis of Disease, 7th edition. Philadelpia: Elsevier Saunders; 528-5289.

Lestari,dkk. (2017). Hubungan Gangguan Fungsi Kognitif dengan Hipertensi Menggunakan Montreal Cognitive Assessment Versi Indonesia (Moca-Ina). JIK, Jilid 11, Nomor 1, Maret, Hal. 12-18

Levine G.N., (2010). Cardiology secrets, Philadelphia, Mosby Elsevier

Ludianita, O, (2013). Pengaruh pendidikan kesehatan terhadap perilaku penderita hipertensi ditinjau dari aspek sikap tentang hipertensi di
Desa Malasan Kecamatan Durenan Kabupaten Trenggalek. Tesis. http:/pasca.uns.ac.id/?p=3506 diakses tanggal 16 Juni 2014.

Mcleod, K. J., \& Jain, T. (2017). Postural Hypotension and Cognitive Function in Older Adults, 3, 1-8. https://doi.org/10.1177/233372141 $\underline{7733216}$

Nies, M.A., \& McEwen, M, (2001). Community health nursing: Promoting the health of population (rd ed.), USA: W.B. Saunders Company.

Notoatmodjo, S. (2010). Ilmu perilaku kesehatan, Jakarta: Rineka Cipta.

Notoatmodjo, S. (2010). Promosi kesehatan teori dan aplikasinya edisi revisi, Jakarta: Rineka Cipta.

Oliveria, S.A., Chen, R.S., McCarthy, B.D., Pharm, C.D \& Hill, M.N. (2005). Hypertension knowledge, awareness, and attitudes in a hypertensive population, Journal of General Internal Medicine, 20 (3). Park, Y.H., Song M., Cho B., Lim,

J., Song, W., \& Kim, S. (2010). The effect of integrated health education and exercise program in communitydwelling older adults with hypertension: a randomized controlled trial, Patient Eduation and Cunseling Journal, 10 (1016).

Purwati, R.D., Bidjuni, H., \& Babakal, A., (2014). Pengaruh penyuluhan kesehatan terhadap pengetahuan perilaku klien hipertensi di puskesmas bahu manado, Journal Unsrat.

Rahajeng, E., \& Tuminah, S. (2009). Prevalensi hipertensi dan determinannya di indonesia; Biomedical and Pharmacytical Research and Development Center National Institute of Health Research and Development. 
Roca, B., Nadal, E., Rovira, R.E., Valls, S., Lapuebla, C., \& Lloria, N. (2003). Usefulness of a hypertension education program, Southern Medical Journal, 96 (11).

Saldana, D.M, Rodriquez S.M., Beltran, L.F, Velasco, M.P., Umama, J.M., Martinez, M.A., et al. (2013). Efecto deun plan educativo en la cappacidal de agencia de autocuidado del paciente con hypertension arterial. Aquichan ISSN 1657-599, 13(3), 363-372.

Smeltzer, S.C., \& Barre, B.G., (2002). Buku ajar keperawatan medikalbedah Brunner \& Suddarth. Jakarta: EGC.
Songjanan, M.E., Marlinah., Hasifah, (2013). Pengaruh pendidikan kesehatan tentang hipertensi kehamilan terhadap sikap pemeliharaan tekanan darah ibu hamil di puskesmas debut kabupaten maluku tenggara, $e$ library stikes nanihasanuddinmerlinelis-212-1artikel, 9(2), 23021721.

Suhardjono, 2009. Hipertensi Pada Lanjut Usia. Dalam: Setiati S, Alwi I, Sudoyo AW, Simandibrata KM, Setiyohadi B, Syam AF (eds). Buku ajar ilmu penyakit dalam jilid I. Edisi ke-5. Jakarta: InternaPublishing, p:899-902 